\title{
Investigating Student's Mathematical Reasoning Ability by Using PMRI Based on Emergent Modeling
}

\author{
Meidiana Sitepu, Nyimas Aisyah, Indaryanti, Weni Dwi Pratiwi* \\ Mathematics Education Department, Faculty of Teacher Training and Education, Univrsitas Sriwijaya \\ "Corresponding author. Email: wenidwipratiwi@unsri.ac.id
}

\begin{abstract}
Mathematics and reasoning are two things that cannot be separated because reasoning is needed to understand mathematics and reasoning can be trained through learning mathematics. The purpose of this study was to determine the mathematical reasoning abilities of junior high school students on a two-variable system of linear equations (SPLDV) material with the use of emergent models as one of heuristic in PMRI (Indonesia Realistic Mathematics Education). The subjects in this study were 6 students of class VIII.2 SMP Negeri 17 Palembang. This research is qualitative research. Data collection techniques are carried out through tests, and interviews. Based on the results of trials, overall from the results of the students' answers to each indicator has appeared in its completion. However, students still experience some minor errors, such as in indicator 1 and indicator 3, some students use tables to solve them, but students are wrong in inputting their scores into the table so that the results obtained by students are not correct. However, after tracing from the interview, it was concluded that the cause of the error was because students were confused with the instructions contained in the student worksheets (LKPD). So that the problems that students experience show that students are less careful in presenting mathematical statements, performing mathematical manipulations, and drawing overall conclusions.
\end{abstract}

Keywords: Emergent Modelling Principles (PMRI), Mathematical Reasoning Ability, System of Linear Equations (SPLDV).

\section{INTRODUCTION}

The 2013 curriculum implicitly emphasizes reasoning as part of the competencies that students must achieve in learning mathematics. Bernard states that reasoning is a thought process to solve mathematical problems based on facts so that students can find a conclusion [1]. Mathematical reasoning is the ability to generalize, analyze, thesis / integrate, solve problems that are not routine and provide the right reasons [2]. According to Hadi [3] the ability to use reason is very important for the process of understanding mathematics. So that when students have good reasoning skills, their mathematical understanding will be good too. Students are said to be able to reason if students are able to use reasoning on patterns and properties, perform mathematical manipulation in making generalizations, compiling evidence, or explaining mathematical ideas and statements [4]. According to Chusna, et al [5], mathematical reasoning is a process of thinking to conclude using critical, creative, and logical thinking. If the ability to reason is not well developed by students, then the student's view of mathematics is only a material that follows a certain set of procedures and formulas and imitates examples without knowing their meaning [6]. Therefore it is important to introduce problem situations related to reasoning as early as possible through learning mathematics in school because reasoning can help students see mathematics as logical and reasonable so that it can increase students' confidence that mathematics is something they can understand. think, justify, and evaluate.

There are five basic mathematical abilities of students formulated by the National Council of Teachers of Mathematics [7], namely: mathematical communication, mathematical reasoning, mathematical problem solving, mathematical connections, mathematical representation. Mathematical reasoning ability is one of the five basic mathematical abilities of students that are important according to NCTM. So it can be concluded, it is very important for students to improve their mathematical reasoning skills. But in reality, the students' mathematical reasoning ability is still low. Based on the research of 
Diniyah, et al (8) which analyzed mathematical reasoning abilities, the results were that $75 \%$ of junior high school students still had scores below the acceptable minimum score. The result of this low reasoning ability is because the teacher's focus is only on student learning outcomes, and does not pay attention to the student learning process. The low ability of students' mathematical reasoning can also be seen from the mathematics learning material SPLDV. Where this material is a class VIII mathematics subject whose problems are in the daily life of students. Because of that SPLDV must be mastered well by students. However, based on the research results of Yusuf, et al [9], the learning outcomes of junior high school students on SPLDV material are still low, this can be seen from the number of students who have difficulty solving contextual story questions related to SPLDV. Some of the mistakes from the students' answers, namely the lack of understanding of the questions, the constraints in changing the story problem into a mathematical model, oriented to formulas, not understanding the concept, not finding the right way, and much more. This is the reason why students cannot solve SPLDV problems properly and appropriately. From the above mistakes, it indicates that students still have difficulty understanding the SPLDV material and this difficulty corresponds to the indicator of mathematical reasoning ability, which means that students' reasoning abilities are still low.

According to Mirlanda, et al [10], student activeness in class is one of the important things in an effort to increase opportunities for students through proper learning. This proper learning is coupled with creating a comfortable learning atmosphere so that students are interested and make themselves able to solve mathematical problems independently, and of course, mathematics learning can be carried out as expected. One of the lessons in accordance with this problem is Indonesian Realistic Mathematics Education (PMRI). PMRI is a form of adaptation of Realistic Mathematics Education (RME), which is a theory that has the aim of supporting students in building or recreating mathematics in problems centered on interactive teaching [11]. The PMRI learning model can help students to make the mathematics learning process more meaningful and interesting so that mathematical concepts that seem difficult and abstract can be understood easily by students. Ulfa [12] states that PMRI is a learning model developed to bring mathematics closer to students. Real problems from everyday life are used as starting points for learning mathematics to show that mathematics is very close to everyday life. Students themselves are expected to participate actively in learning and teachers must provide opportunities for students to build their own knowledge and understanding.

PMRI has 3 important principles in designing mathematics learning, namely [13]: 1) guided reinvention and didactical phenomenology; 2) progressive mathematization; 3 ) emergent modelling. In the process of PMRI-based learning, it is necessary to pay attention to the role of the model of the situation which will later become a model for mathematical thinking from the principles of emergent modeling which is very helpful for bringing out students' reasoning abilities (Bakker, 1999), where the use of this model is to develop informal knowledge and knowledge. the beginning according to the situation the students have becomes formal knowledge of mathematics. Emergent modeling itself is the development of a model independently with the direction of the researcher, the model developed by students can bridge the gap between informal knowledge and formal knowledge. In the book written by Van den Hauvel [14], it is said that when students have more experience with the same problem, their attention will turn to the relationship between mathematics and strategy. As a result, the model becomes more important as a basis for mathematical reasoning then as a way to solve the problem. In this situation, the model begins to become a referential basis for the level of formal mathematics. Researchers use the principle of emergent modeling, wherein emergent modeling it is necessary to pay attention to the use of a model of the situation which will later become a model for mathematical thinking [15], where the use of this model is to develop informal knowledge and initial knowledge according to the situation students have into knowledge. formal mathematics. This is consistent with the existing indicators of mathematical reasoning abilities so that the principle of emergent modeling in PMRI can be a good mathematics learning solution to overcome students' low mathematical reasoning abilities. From the results of research from Pratiwi et al. [16] (2020) learning using models from emergent modeling can support students' understanding at the early stages of PMRI, namely the situational stage and the referential stage which is a process model of emergent modeling principles. Which later students will be able to use their mathematical reasoning abilities to find solutions by thinking logically and critically to get the conclusion of the strategies they use with their mathematical thinking models. This research is also in line with the results of research from Büscher \& Schnell [17] (2017) which states that emergent modeling has also proven useful in guiding the process in the learning environment in terms of bringing out students' reasoning processes. So that emergent modeling can be the right solution to lead students to bring up their mathematical reasoning skills.

\section{RESEARCH METHODS}

The method used in this study is qualitative research, with a research focus to see the mathematical reasoning abilities of junior high school students on the material of Two-Variable Linear Equation Systems (SPLDV) by applying the principle of emergent modelling (PMRI). Qualitative research is research that seeks to understand and interpret the meaning of an event of interaction with 
human behaviour in certain situations according to the perspective of the researcher himself [18]. Qualitative research is also used to examine the conditions of natural objects, where the researcher is a key instrument and the results of qualitative research emphasize meaning rather than generalization. The purpose of this study was to see students' mathematical reasoning abilities that emerged when applied emergent modelling (PMRI) principles and describe everything based on the things that happened in the environment being studied.

This research will be conducted online with data collection techniques consisting of observation, tests, and interviews. The research subjects in this study were 6 students VIII.2 JHS Negeri 17 Palembang, students were selected based on the recommendation of the teacher. The seven indicators and their descriptors are used by researchers to measure students' mathematical reasoning abilities in Aprilianti, et al [19] which are based on the technical regulations of the Directorate General of Primary and Secondary Education of the Ministry of National Education Number 506 / Kep / PP / 2004 dated 11 November 2004, namely:

- Presents mathematical statements orally, in writing, pictures, and diagrams

- $\quad$ Proposing allegation

- $\quad$ Performs mathematical manipulation

- Draw conclusions, compile evidence, provide reasons or evidence for the correctness of the solution

- Checking the truth of an arguments

- Find patterns or the nature of the symptoms of mathematically to make generalizations

- $\quad$ Conclude from statements

In conducting research, researchers follow research procedures, namely through the preparation stage that prepares carefully both the school used for research, research subjects, research permits, and the media and learning tools used during the research. Then proceed with the implementation phase which was carried out for 2 meetings. Observations and tests were carried out online via zoom meetings. Observations are made by seeing and recording student activities during learning, and tests are given through the WhatsApp group. The last stage is the stage of data analysis, observation, tests, and interviews. The results of the test data, which is used to analyze the results of student data lie in the LKPD which is following the principles of emergent modelling and the characteristics of PMRI. Students are given problems and students solve them based on their abilities through students' experiences in their daily life and also through the creativity of the ideas and strategies that students get when identifying the problems given. The data analysis of the test results was carried out after the students had solved all the problems in the LKPD, then continued by describing the things that arose from the research subject. Analysis of test result data is also supported by observations and interviews. The interview that was conducted aims to obtain information that wants to be extracted more from research subjects based on the results of written tests. The type of interview conducted is semi-structured, with the aim that research subjects can provide more open information [20]. Interviews were conducted online through the zoom meeting application.

\section{RESULTS AND DISCUSSION}

Activity data from students were obtained based on the results of observations, tests, and interviews. The observation data itself is taken from the learning process through the zoom meeting recorded during the learning process, this is done because the Covid-19 pandemic requires a distance learning process (PJJ), so this is an alternative for researchers to carry out learning and meet students online. Then the interview was conducted through a zoom meeting so that the researcher could see directly the subject's face during the interview.The following is an explanation of the indicators of mathematical reasoning abilities that arise from the results of students' answers:

Table 1. The appearance of indicators on the results of student answers.

\begin{tabular}{|c|c|c|c|c|c|c|c|c|}
\hline \multirow{2}{*}{ Subject } & & \multicolumn{7}{|c|}{ Indicator } \\
\hline & & 1 & 2 & 3 & 4 & 5 & 6 & 7 \\
\hline \multirow[t]{2}{*}{ A } & Q1 & $\sqrt{ }$ & $\sqrt{ }$ & $\sqrt{ }$ & $\sqrt{ }$ & $\sqrt{ }$ & $\sqrt{ }$ & $\sqrt{ }$ \\
\hline & Q2 & $\sqrt{ }$ & $\sqrt{ }$ & $\sqrt{ }$ & $\sqrt{ }$ & $\sqrt{ }$ & $\sqrt{ }$ & $\sqrt{ }$ \\
\hline \multirow[t]{2}{*}{ B } & Q1 & $\sqrt{ }$ & $\sqrt{ }$ & $\sqrt{ }$ & $\sqrt{ }$ & $\sqrt{ }$ & $\sqrt{ }$ & $\sqrt{ }$ \\
\hline & Q2 & $\sqrt{ }$ & $\sqrt{ }$ & $\sqrt{ }$ & $\sqrt{ }$ & $\sqrt{ }$ & $\sqrt{ }$ & $\sqrt{ }$ \\
\hline \multirow[t]{2}{*}{$\mathrm{C}$} & Q1 & $\sqrt{ }$ & $\sqrt{ }$ & $\sqrt{ }$ & $\sqrt{ }$ & $\sqrt{ }$ & $\sqrt{ }$ & $\sqrt{ }$ \\
\hline & Q2 & $\sqrt{ }$ & $\sqrt{ }$ & $\sqrt{ }$ & $\sqrt{ }$ & $x$ & $x$ & $x$ \\
\hline \multirow[t]{2}{*}{$\mathrm{D}$} & Q1 & $\sqrt{ }$ & $\sqrt{ }$ & $\sqrt{ }$ & $\sqrt{ }$ & $\sqrt{ }$ & $\sqrt{ }$ & $\sqrt{ }$ \\
\hline & Q2 & $\sqrt{ }$ & $x$ & $\sqrt{ }$ & $\sqrt{ }$ & $x$ & $\sqrt{ }$ & $\sqrt{ }$ \\
\hline \multirow[t]{2}{*}{$E$} & Q1 & $\sqrt{ }$ & $\sqrt{ }$ & $\sqrt{ }$ & $\sqrt{ }$ & $\sqrt{ }$ & $\sqrt{ }$ & $\sqrt{ }$ \\
\hline & Q2 & $\sqrt{ }$ & $\sqrt{ }$ & $\sqrt{ }$ & $\sqrt{ }$ & $\sqrt{ }$ & $\sqrt{ }$ & $\sqrt{ }$ \\
\hline \multirow[t]{2}{*}{$\mathrm{F}$} & Q1 & $x$ & $\sqrt{ }$ & $x$ & $\sqrt{ }$ & $\sqrt{ }$ & $x$ & $x$ \\
\hline & Q2 & $\sqrt{ }$ & $\sqrt{ }$ & $\sqrt{ }$ & $\sqrt{ }$ & $x$ & $x$ & $\times$ \\
\hline
\end{tabular}

Information:
$\sqrt{ } \quad:$ Appear
$\times \quad$ : Not Appear
Q1 : Question 1
Q2 : Question 2 
Based on the results of the emergence of indicators of students 'mathematical reasoning abilities, it can be seen that the average of all indicators appears in students' answers. However, from each indicator, there are subjects who experience minor errors in their answers and there are those that do not appear, following the discussion.

a. Presents mathematical statements orally, in writing, pictures, and diagrams and performs mathematical manipulations.

Indicators 1 and indicator 3 are among the indicators that the students answered the most. In indicator 1, students are expected to be able to present, namely expressing / writing / explaining the mathematical statements contained in the questions (which can be the information contained in the questions) presented orally, in writing, pictures, and diagrams. Students understand the meaning of the problem in question. And in indicator 3 students are expected to be able to use their mathematical modeling skills in answering questions where manipulation skills are needed in answering questions. The following are the results of the answers from students based on each indicator.

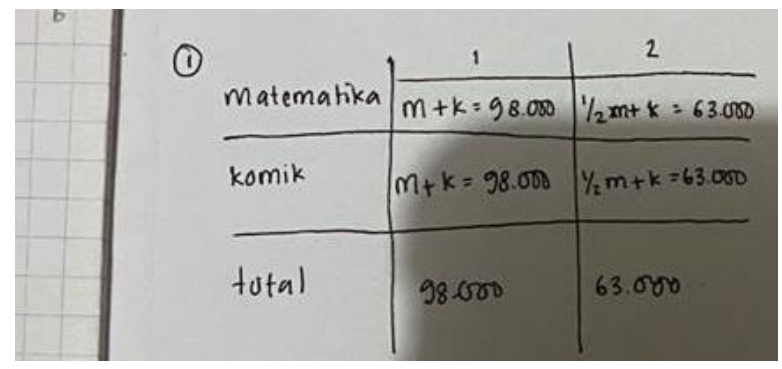

Figure 1. Student answer for indicator 1

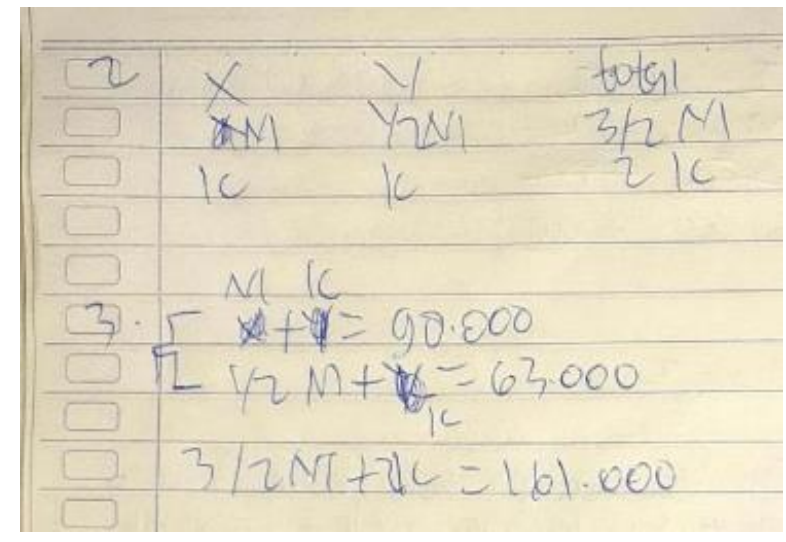

Figure 2. Student answer for indicator 1

From the answers of the two students, it can be seen that students can write down the information contained in the problem into tables, but there are errors in inputting data. For students' answers figure 1, it appears that students only write the equations they get into the table and for students figure 2 it appears that students are confused in understanding the meaning of the information contained in the table, wherein the table has been given information that the variables have been exemplified and when asked in the student interview can explain and know that in the second step $\mathrm{x}$ and $\mathrm{y}$ are assumed to be math and comic books. However, students experience errors in understanding the description "total" in the table, which means the total price of the book contained in the questions. From the results of the interview, the students thought that the meaning of the information was the total of the sum of the variables $\mathrm{x}$ and $\mathrm{y}$ in each row of the table. And after being asked further, the students knew where their mistakes were and were able to correct their answers. The following are the results of the student figure 2 interviews on indicator 1 .

Researcher : Why in filling in the table, you write down the whole result of the equation?

Subject : Yes miss, because what is known in the problem $m+k=98000$ and $1 / 2 m+k=$ 63000, so I just write it down because it is also labeled there are explanations I and II which means that is equation 1 and equation 2, yes right miss?

Researcher: Yeah right, but try to see the information on the far left, what's the point?

Subject : Well, its point in telling math and comics

Researcher : That's right if to show him mathematics and comics, then do you still need to make the variables $m$ and $k$ into the table?

Subject : Yes to miss, two times the job is done

Researcher : That's right, so use the table to shorten your answer. Now try to also pay attention to why there is information I and II

Subject : To show which equation 1 and equation 2 miss

Researcher : Yes, that's right, that means if you are complete, you want to show equation one and for the math value, what should you write in the first column?

Subject : Ohh, understand miss. Does that mean $1.1 / 2.1 .1$, miss?

From the results of the interview above, it can be seen that the mistakes that students (a) made in inputting data were because students still did not know the function of the information given in the table. However, students understand where the mistakes are and can correct and explain the results well. The conclusion between student's (a) and student (b) 's answer errors for each indicator is the same, namely because students are 
confused about understanding the commands of the questions. This is in line with the results of the analysis by Ulifah, et al [21], where the errors that students experience indicate that students want to quickly complete their answers, and do not reexamine these answers. Then also because students are confused in understanding the command questions.

b. Checking the truth of an arguments.

In this indicator, students are expected to be able to reexamine the problems contained in the questions and investigate the truth of a statement. The following are the results of the students' answers.

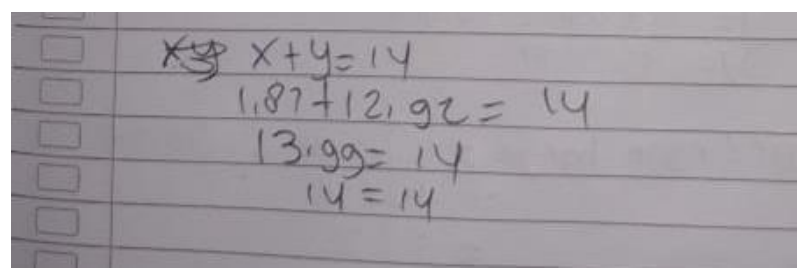

Figure 3. Student answer for indicator 5

In the students' answers above, it can be seen that the students are trying to prove the results of the answers are correct or not, even though the results of the answers the students are not correct, the students are trying to prove the results of the answers. After being interviewed, it was found the location of the students' answers, and the students understood their mistakes. This student error is in line with the results of the analysis from Suraji, et al. [22], namely because the student made a mistake in the calculation so that the solution was not correct.

c. Conclude from statements.

What is expected in indicator 7 is that students can pour their thoughts on the conclusions of the results of solving the problems given. In this indicator, there are students who do not appear indicators. The following are the results of two student answers.

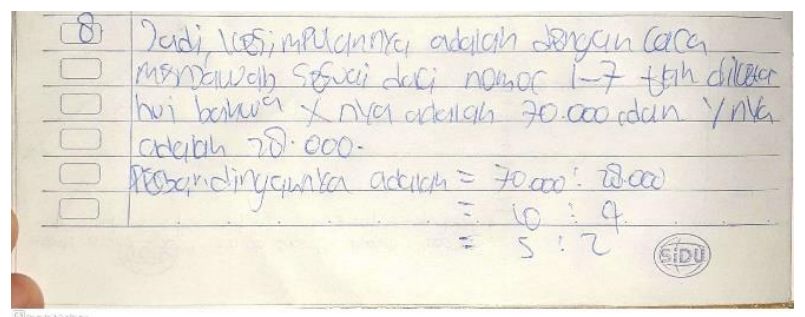

Figure 4. Student's answer for indicator 7

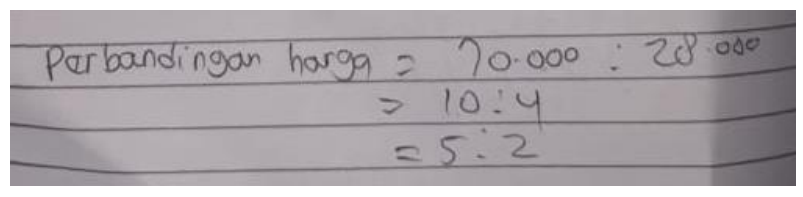

Figure 5. Student's answer for indicator 7

In the answer above, it is seen in the answers to subjects figure 4 and figure 5 . Subject figure 4 can explain well the conclusions he can. However, for the answer to the subject figure 5, it appears that students only write down the results without making conclusions. After being interviewed, the student said that he forgot to write it down completely and after that, he could explain the conclusion of the answer well. The errors experienced by these students are in line with the results of research from Haryati, et al [23], namely that there are students who are not used to making conclusions because students think that finding the final result is considered complete and correct.

\section{CONCLUSION}

Learning in class should be learning that can create a comfortable learning atmosphere, so that students become active, interested, and make themselves able to solve mathematical problems independently. So that starting from comfortable learning, students 'reasoning abilities can be developed well because students' reasoning abilities are a must to be trained so that students are able to have a thinking process that can draw conclusions using critical, creative, and logical thinking. This study concludes that based on the results of students 'answers, all indicators appear, but there are some students' answers that are not quite right on indicator 1 that is present mathematical statements orally, in writing, pictures, and diagram, indicator 3 that is performs mathematical manipulation, and indicator 7 that is conclude from statements. This is because students experience confusion in understanding the information contained in the LKPD and forget the questions from the questions because too focused on looking for the main result. Then there are also the results of students' answers whose indicators do not appear, but when being interviewed these indicators can be fulfilled properly by students.

\section{ACKNOWLEDGMENTS}

The author would like to thank the teachers and schools of SMP Negeri 17 Palembang for their full support for this research, who have provided classrooms and their time in collecting data. A big thank you also to the supervising lecturers from the Mathematics Education Study Program who have helped in writing and compiling this paper, and who has also helped smooth the course of this research by providing various assistance. This article was funded by DIPA of Public Service Agency of Universitas Sriwijaya 2020. SP DIPA023.17.2.677515/2020, revision 1, On March 16, 2020. In accordance with the Rector's Decree Number: 0684/UN9/SK.BUK.KP/2000. On July 15, 2020.

\section{REFERENCES}

[1] Yuliani, D., Zulkardi, Z., \& Hapizah, H., Kemampuan Penalaran Matematis Siswa SMP 
Kelas VIII dalam Menyelesaikan Soal PISA (Doctoral dissertation, Sriwijaya University), 2018

[2] Konita, M., Asikin, M., \& Asih, T. S. N., Kemampuan Penalaran Matematis dalam Model Pembelajaran Connecting, Organizing, Reflecting, Extending (CORE), In PRISMA, Prosiding Seminar Nasional Matematika, 2019, vol. 2, pp. 611-615

[3] Hadi, W., Meningkatkan Kemampuan Penalaran Siswa SMP Melalui Pembelajaran Discovery Dengan Pendekatan Saintifik, Kalamatika: Jurnal Pendidikan Matematika, 2016, 1(1), 93-108.

[4] Safitri, I. R., Kemampuan Pemahaman Matematis Siswa SMP melalui Problem Based Menggunakan Soal PISA, Skripsi, 2019 DOI: http://dx.doi.org/10.31949/th.v4i1.1380

[5] Chusna, C. A., Rochmad, R. A., \& Prasetyo, A. P. B., Mathematical Resilience Siswa pada Pembelajaran Team Assisted Individualization dalam Upaya Meningkatkan Kemampuan Penalaran Matematika, In Prosiding Seminar Nasional Pascasarjana (PROSNAMPAS), 2019, vol. 2, no. 1, pp. 157-162

[6] Madio, S. S., Pengaruh Pembelajaran Berbasis Masalah Terhadap Kemampuan Penalaran Dan Komunikasi Matematis Siswa Smp Dalam Matematika, Jurnal Pendidikan Matematika Sriwijaya, 2016, 10(2), 93-108

[7] NCTM, Principles and Standards, 2000 Diambil kembali dari www.nctm.org:https://www.nctm.org/standards/

[8] Diniyah, A. N., Akbar, G. A. M., Akbar, P., Nurjaman, A., \& Bernard, M., Analisis Kemampuan Kemampuan Penalaran dan Self Confidence Siswa SMA dalam Materi Peluang, Journal on Education, 2018, 1(1), 14-21. DOI : https://doi.org/10.31004/joe.v1i1.5

[9] Yusuf, A., \& Fitriani, N., Analisis Kesalahan Siswa Smp Dalam Menyelesaikan Soal Persamaan Linear Dua Variabel Di Smpn 1 Campaka Mulya-Cianjur, JPMI (Jurnal Pembelajaran Matematika Inovatif), 2020, 3(1), 59-68 DOI http://dx.doi.org/10.22460/jpmi.v3i1.p\%25p

[10] Mirlanda, E. P., Nindiasari, H., \& Syamsuri, S., Pengaruh Pembelajaran Flipped Classroom terhadap Kemampuan Penalaran Matematis Ditinjau dari Gaya Kognitif Siswa, Prima: Jurnal Pendidikan Matematika, 2020, 4(1), 11-21. DOI : http://dx.doi.org/10.31000/prima.v4i1.2081

[11] Gravemeijer, K., Local instruction theories as means of support for teachers in reform mathematics education. Mathematical thinking and learning, 2004, 6(2), 105-128. DOI : https://doi.org/10.1207/s15327833mt10602_3
[12] Ulfa, A., Penerapan Model Pembelajaran Realistic Mathematic Education (RME) untuk Meningkatkan Aktivitas dan Hasil Belajar Matematika Siswa, 2016, Universitas Lampung : Bandar Lampung.

[13] Zulkardi, Z., \& Putri, R. I. I., Pengembangan blog support untuk membantu siswa dan guru matematika Indonesia belajar pendidikan matematika realistic Indonesia (PMRI), Jurnal inovasi perekayasa pendidikan (JIPP), 2010, 2(1), 124

[14] Van den Heuvel-Panhuizen, M., National Reflections on the Netherlands Didactics of Mathematics, 2016 DOI : 10.1007/978-3-03033824-4

[15] Bakker, A., Design research in statistics education: On symbolizing and computer tools (Doctoral dissertation), 2004

[16] Pratiwi, W. D., Susanti, E., \& Araiku, J., Supporting mathematics learning in situational-referential phase with emergent modelling, In Journal of Physics: Conference Series, 2020, vol. 1480, no. 1, p. 012002, IOP Publishing

[17] Büscher, C., \& Schnell, S., Students' Emergent of Statistical Measures - a Case Study Statistics, Education Research Journal, 16(2), 2017

[18] Gunawan, I., Metode penelitian kualitatif, Jakarta: Bumi Aksara, 143, 2013

[19] Aprilianti, Y., \& Zanthy, L. S., Analisis Kemampuan Penalaran Matematik Siswa SMP pada Materi Segiempat dan Segitiga, Journal on Education, 2019, 1(2), 524-532. DOI : https://doi.org/10.31004/joe.v1i2.167

[20] Sugiyono, S. (2007). Metode Penelitian Kualitatif Kuantitatif dan R \& D. Bandung: Alfabeta.

[21] Ulifah, S. N., \& Effendi, D., Hasil Analisis Kesalahan Siswa dalam Menyelesaikan Soal Matematika Pada Materi Relasi (Error Analysis of Students in Math Problem Solving in The Matter Relationship), Jurnal Pendidikan Matematika STKIP PGRI Sidoarjo, 2014, 2(1)

[22] Suraji, S., Maimunah, M., \& Saragih, S., Analisis kemampuan pemahaman konsep matematis dan kemampuan pemecahan masalah matematis siswa smp pada materi sistem persamaan linear dua variabel (SPLDV), Suska Journal of Mathematics Education, 2018, 4(1), 9-16. DOI : http://dx.doi.org/10.24014/sjme.v4i1.5057

[23] Haryati, T., Analisis kesalahan siswa SMP kelas VII dalam menyelesaikan soal cerita pemecahan masalah berdasarkan prosedur newman, 2015, Doctoral dissertation, Universitas Semarang 